\title{
ФОРМУВАННЯ АСЕРТИВНОЇ ПОВЕДІНКИ СТУДЕНТІВ - ПСИХОЛОГІВ: СТРУКТУРНО-КОМПОНЕНТНИЙ АНАЛІЗ ДОСЛІДЖЕННЯ
}

УДК: 159.99

\section{Мариук Лариса Миколаӥвна \\ Кандидат психологічних наук, дочент кафедри педагогіки та психології Державного вищого навчального закладу «Ужгородський національ- ний університет», м. Ужгород (Украӥна)}

\begin{abstract}
Анотація. У статті розкрито погляди вчених на структурно-компонентну складову асертивної поведінки; визначено й обтрунтовано власні міркування щзодо розвитку й формування асертивної поведінки студентів у сучасних витах. Визначено змістове поле асертивної поведінки студентів у навчальному середовищі, щзо обумовлене суб'єктністю особистості в самоутверджувальній поведіниі й виражається в самостійності, незалежності від інших обставин, в умінні відстоювати свої права і думки при самоповазі й повазі до інших людей. Структурними компонентами визначено: ціннісно-мотиваційний, когнітивний, рефлексивно-оцінний, регулятивний. На основі емпіричних зрізів констатовано недостатній рівень сформованості асертивної поведінки у студентів, щэо підтверджує актуальність окресленої нами проблеми і ї̈ розв'язання на рівні структурних компонентів.
\end{abstract}

Ключові слова: асертивність, асертивна поведінка студентів, структурні компоненти, навчальне середовище, міжособистісна взаємодія.

Постановка проблеми. В умовах соціальної напруги зростає здатність особистості виявляти адекватну поведінку в критичних ситуаціях як своєчасній реакції на динаміку соціально-психологічних змін, впливу різних чинників й зберігати психологічну рівновагу та етичне ставлення до інших індивідів у суспільних відносинах. Йдеться про асертивну поведінку, розвиток якої зумовлений активізацією позитивних психічних якостей особистості, що є важливими для її ста- новлення не лише як об'єкта, але й суб'єкта міжособистісної взаємодії. За цієї умови асертивна поведінка набуває значущості у прикладному (професійному) сенсі, є засобом досягнення взаєморозуміння і позитивної атмосфери у міжособистісній взаємодії, дозволяє забезпечити успішне професійне зростання (О. Бондарчук, В. Зазикін, В. Клименко, Е. Климов, Т. Кудрявцева, Г. Ложкін, Ю. Поваренков, Л. Подоляк, Н. Пряжніков, В. Юрченко та ін.). 
Аналізостанніх досліджень і публіка-

цій. Власне поняття «асертивна поведінка» представлене у дослідженнях зарубіжних психологів: зовнішня поведінкова модель успішної людини (Г. Бейєр, М. Джеймс, Д. Джонгвард, Г. Фенстрейхейм); внутрішній

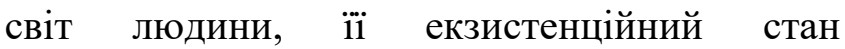
(А. Маслоу, Е. Фромм, К. Роджерс, В. Франкл, Ф. Перлс, Г. Оллпорт та ін.); конструктивний спосіб міжособистісної взаємодії, що є альтернативою деструктивного способу - маніпуляції та агресії (Р. Алберті, М. Емонс, С. Бішоп, Дж. Вольпе, П. Джакубовські, А. Ланджа, Р. Мейє,У. Петерман, С. Солтер, Р. Ульріх); гармонійне поєднання особистісних якостей людини, що відображаються у формі конкретних світоглядних позицій та позитивній спрямованості, у знаннях про людську сутність, у вміннях і навичках ефективної взаємодії (В. Каппоні, Т. Новак), визначенні й обгрунтуванні структурних компонентів іiі розвитку. Різні аспектиасертивної поведінки особистості віддзеркаленоу працях Г. Балла,О. Бондарчук, Є. Головахи, О. Донченка, ， М. Савчина, Л. Сохань, В. Татенка, Т. Титаренко та ін. українських учених.

Мета статті - визначити та експериментально обгрунтувати структурнокомпонентну складову асертивної поведінки студентів-психологів та

Виклад основного матеріалу і результатів дослідження. Асертивна поведінка особистості в сучасних психологічних досліджен- нях розглядається як така, що забезпечує іiі успішність, нівелює деструктивні психологічні прояви (Г. Бейєр, М. Джеймс, Д. Джонгвард, Г. Фенстрейхейм та ін.) і виражається, передусім, в самостійності, незалежності від інших, в умінні відстоювати свої права та думки при самоповазі й повазі до інших. Уявним конструктом, услід за В. Каппоні, Т. Новак й ін. $\epsilon$ «модель успішної людини» 3 урахуванням структурних іiі компонентів. Теоретичною основою моделі $є$ визначення відмінностей між асертивною, пасивною і агресивною поведінкою людини, що полягає в способі реагування на різні ситуації: «Я не важливий, а ви важливі» - пасивна реакція; «Я важливий, а ви - ніщо»агресивна, «Я важливий, ви важливі, ми важливі» - асертивна. Людина, яка уміє і налаштована відстояти своє право на переконання, здатна усвідомлювати власні права, але одночасно визнає права і переконання іншої людини - це людина ідеального майбутнього. Зауважимо, що бажана модель майбутнього і людини в ньому не сформується, якщо не виховувати сучасну молодь на засадах і традиціях асертивності. Визначаючи структурні компоненти асертивної поведінки майбутніх психологів грунтувались на позиціях учених, які характеризують їі як комплексну інтегровану якість, що формується на засадах гуманності, толерантності. За переконаннями Д. Леонтьєва, структурними компонентами формування асертивної поведінки студентів у 
процесі навчання є: особистісній - як високий рівень самооцінки й самоповаги людини; емоційно-ціннісний - як сміливість у соціальних контактах, уміння керувати своїми реакціями, прийняттям іншого, впевненістю у собі, довірою до себе; когнітивний - як переконання людини у власній ефективності, гнучкості мислення, адекватній оцінці ситуації; поведінковий - у виявленні незалежності, відповідальності, наполегливості, готовності до ризику й конструктивної агресії [4]. Становить інтерес структура формування особистості майбутнього психолога, розроблена В. Шамієвою і К. Воробьйою. Автори розглядають їі крізь призму когнітивно-сутнісних, афективних і поведінкових структурних компонентівасертивної поведінки [10]. Когнітивно-сутнісний компонент полягає в орієнтуванні й адекватній оцінці ситуації, доцільному варіюванні способів дії й продуктивному перетворенні проблемних ситуацій (гнучкість мислення); прогнозуванні саморозвитку й саморуху, визначенні свого «Я» в навколишньому світі на основі усвідомлення змісту і цінностей свого життя; афективний - у прийнятті іншого, впевненості у собі, довірі до себе, де прийняття іншого - особлива якість асертивної поведінки, яку можна розцінювати як почуття самозбереження, що проектується на інших людей. Потреба в самозбереженні, благополуччя й безпека інших стають факторами впевненого поводження, щиросердечного спокою в умовах, що змінюються; життєді- яльності; поведінковий - виявляється в незалежності, відповідальності, наполегливості (напористості), готовності до ризику й конструктивної агресії. О. Тарновська пропонує розглядати компонентну структуру асертивної поведінки як інтегроване утворення, що містить три взаємообумовлені та взаємозалежні між собою підструктури: 1) функціональну - охоплює такі компоненти, як: мотиваційний - мотиви вибору професії, орієнтація на цінності діяльності; когнітивний - знання спеціальності; операційну - наявність умінь i навичок, необхідних для вирішення професійних завдань, моделювання власної діяльності; 2) емоційну - налаштованість на вирішення завдань, упевненість у собі, стан задоволеності професією, задоволення від роботи; 3) особистісну - професійно значущі якості особистості [2]. Акцент на особистісних та поведінкових компонентах робить $Є$. Хохлова. 3-поміж них виділяе такі критерії та їх показники як:

- позитивна відкритість, емоційна включеність поведінки на противагу інертності; енергійність як вираз внутрішньої сили, необхідної для творчої активності, наполегливість як здорове вираження своїх позицій;

- сміливість у творенні; сумнів як показник розвитку самостійного і творчого пошуку; здорове занепокоєння як показник активної діяльної життя і внутрішнє хвилювання (напруженість) на протива- 
гу бездіяльності, пов'язаної з продуктивністю життя; впевненість у собі як показник ціннісного ставлення до себе та інших; соціальна сміливість та ініціативність у соціальних контактах як вираз активності в напрямку розвитку i пізнання;

- тимчасова спрямованість особистості, пов'язана 3 діяльністю пізнання і викликана цінністю пізнання [10].

Наведене вище дало можливість визначити власне бачення формування асертивної поведінки студентів за такими структурними компонентами: ціннісно-мотиваційній, когнітивний, рефлексивно-оцінний, регулятивний. Вкажемо на їх особливості та специфіку в процесі оволодіння студентами психологамиасертивної поведінки в процесі їх професійного становлення.

Ціннісно-мотиваиійний - відображає спосіб існування особистості професіонала. Цінності учасників навчального процесу утворюють систему ціннісних орієнтацій як сукупність найважливіших якостей внутрішньої структури особистості, що є для неї особливо значущими.

Когнітивний- містить обізнаність щодо змісту, показників і чинників асертивної поведінки, особливостей їх прояву в майбутній професійній діяльності. Основними його критеріями $є$ знання про себе (самопізнання), про власні можливості, які спрямовані на реалізацію цілей та прагнень у навчально- професійній діяльності; самовдосконалення та самооцінку.

Рефлексивно-оцінний- визначає рівень сформованості самооцінки, власної значущості, пізнання себе і самореалізацію у процесі навчальної взаємодії. Регулятивний компонент визначає здатність розв'язувати проблемні ситуації професійної діяльності в асертивний спосіб; контроль емоційних проявів у поведінкових ситуаціях. Він проявляється в незалежності, відповідальності, наполегливості (напористості), готовності до ризику i конструктивної агресії. Ключовим параметром регулятивного компонента $\epsilon$ конструктивна (низька) агресивність.

Регулятивний компонент визначає здатність розв'язувати проблемні ситуації професійної діяльності в асертивний спосіб; контроль емоційних проявів у поведінкових ситуаціях. Він проявляється в незалежності, відповідальності, наполегливості (напористості), готовності до ризику і конструктивної агресії. Ключовим параметром регулятивного компонента $€$ конструктивна (низька) агресивність.

Дослідження ціннісно-мотиваційного компонента асертивної поведінки грунтувалося на результатах опитувальника Т. Данилової [3], і включало діагностику типів спрямованості особистості психолога: гуманістич$н a$, за якої цілі, інтереси й потреби інших людей набувають провідної цінності для майбутнього психолога; екзистенціальна, за якої переважаючою цінністю виступає потреба у 
внутрішній діяльності, що характеризується високим рівнем самоаналізу, прагненням до самовдосконалення і самореалізації; прагматична, що зосереджує особистість на плануванні професійної діяльності та досягнення успіху в ній; вид спрямованості, за якого системою домінувальних потреб $є$ планування професійної діяльності та успіхи в ній; егоцеентрична, за якої цілі, інтереси, потреби особистості мають, переважно, егоїстичний характер і посідають центральне місце в ієрархії цінностей.

Високий рівень ціннісно-мотиваційного компонента визначався в разі переважання гуманістичної та екзистенційної спрямованості; низький - егоїстичної. Усі інші співвідношення показників спрямованості за методикою Т. Данилової віднесено до середнього рівня ціннісно-мотиваційного компонента асертивної поведінки. Така ієрархія цілком відповідає і думці інших авторів [3]. Так, С. Максименко зазначає, що не кожна людина може стати соціальним працівником. Визначальним критерієм є система $\dddot{11}$ духовних цінностей. Ціннісні установки професійного становлення майбутнього психолога у всіх різновидах зводяться до загальнолюдських: поваги, честі та почуття власної гідності людини: унікальності іiї особистості [6].

Дослідження когнітивного компонента асертивної поведінки грунтувалося на результатах авторської анкети, питання якої були спрямовані на виявлення обізнаності дослі- джуваних психологів щодо сутності, рівнів і чинників асертивної поведінки, а також особливостей іiі прояву в професійній діяльності психолога та анкети «Асертивна поведінка особистості». Анкета призначена для оцінки асертивності - здібності не діяти на шкоду кому-небудь, поважати права інших людей, але при цьому, не дозволяючи «сукати із себе мотузки» («витирати об себе ноги»). Бажаної мети асертивна людина досягає, не заподіюючи шкоди навколишнім; домагається свого, не маніпулюючи опонентами за допомогою почуття провини або яким-небудь іншим способом з розряду прийомів емоційного шантажу; уміє схилити інших до надання допомоги або люб'язності; не замикається в собі, отримуючи відмову в тому, на що власне, і не мала права розраховувати. При зіткненні інтересів здатна домовитися і знайти компромісне рішення, яке задовольняє обидві сторони. Спираючись на підхід С. Медведєвої [7], наприкінці опитування досліджуваним пропонувалося закінчити фразу «Я поводжуся впевнено, якщо...». Високий рівень когнітивного компонента визначався в разі високого рівня знань за всіма питаннями анкети та чіткого визначення показників асертивної поведінки у заключному незавершеному реченні, низький - у разі відсутності чи низького рівня знань, а також нездатності виокремити обгрунтовані показники асертивної поведінки в незавершеному реченні анкети. Усі інші співвідношення показників було віднесено до серед- 
нього рівня когнітивного компонента асертивної поведінки майбутніх психологів. Рефлексивно-оцінний компонент визначався за методикою М. КунаТ. Мак-Партланда «Хто Я?» у модифікації Т. Рум'янцевої [9], після виконання якої досліджувані оцінювали кожну відповідь знаками «+», «士», «-» та «?», якщо вони не могли вирішити, подобається їм ця риса в собі чи ні. Особлива увага при цьому зверталася на частоту використання знаку «土», що відповідно до трактування авторів методики говорить про здатність людини розглядати те чи інше явище 3 двох протилежних

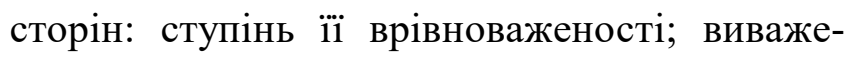
ність позиції щодо емоційно значущих явищ. Умовно виокремлюють осіб «емоційнополярного», «врівноваженого» та «такого, що сумнівається» типів. До людей емоційнополярного типу відносяться ті, хто всі свої ідентифікаційні характеристики оцінюють лише як такі, що подобаються чи ні, зовсім не використовуючи при оцінюванні знак «плюсмінус». Для таких людей характерний максималізм в оцінках, перепади в емоційному стані, щодо них можна сказати «від любові до ненависті один крок». Це, як правило, люди, у яких відносини з іншими людьми залежать від того, наскільки їм людина подобається чи не подобається. Якщо кількість знаків « » досягає 10-20\% від загального числа знаків, то таку особу відносять до врівноваженого типу. Для них, порівняно $з$ особами емоційно-полярного типу, характерна велика стресо- стійкість, швидке (мобільне) розв'язування конфліктних ситуацій, здатність підтримувати конструктивні відносини з різними людьми (з тими, які їм подобаються, і тими, які не викликають особливої симпатії); терпиміше ставлення до недоліків інших людей. Якщо кількість знаків «土» перевищує 30-40\% від загального числа знаків, то таку особу можна віднести до типу, що сумнівається. Така кількість знаків «土» може бути у людини, що переживає кризу в своєму житті, та свідчити про нерішучість як рису характеру: при прийнятті рішення, коли вона довго сумнівається, розглядаючи різні варіанти. Також бралася до уваги наявність знака «?», який при оцінці ідентифікаційних характеристик говорить про здатність людини переносити ситуацію внутрішньої невизначеності, а отже, побічно свідчить про іiї готовність до змін. У цілому знаки «土» $\mathrm{i}$ «?» застосовують ті люди, які, зазвичай, швидше виходять на рівень самостійного вирішення власних проблем. Таким чином, досліджуваних було віднесено до високого («врівноважений тип»), середнього («тип, що сумнівається») та низького («емоційно-полярний тип») рівнів емоційної врівноваженості. Крім того, за вказаною методикою визначався рівень рефлексії, виходячи з того, що досліджуваний з більш розвиненим рівнем рефлексії дає в середньому більше відповідей, ніж з менш розвиненим уявленням про себе (або є більш «закритим»). Отже, про низький рівень рефлексії йшлося, 
коли за час, відведений на тестування (15 хвилин), досліджуваний майбутній психолог міг дати не більше 8 відповідей, а про досить високий рівень рефлексії - понад 15 різних відповідей на питання «Хто Я?». Також нас цікавило, співвідношення соціальних ролей i індивідуальних характеристик, таких, як упевненість, відповідальність, довіра, за якими можна визначити, наскільки людина усвідомлює і приймає свою унікальність та наскільки для неї є важливою приналежність до певної групи людей. Відсутність у самоописі індивідуальних характеристик під час зазначення лише соціальних ролей («студент», «перехожий», «виборець», «член сім'ї», «громадянин») може свідчити про недостатню впевненість у собі, наявність у людини побоювань у зв'язку з саморозкриттям, виражену тенденцію до самозахисту. Відсутність же соціальних ролей за наявності індивідуальних характеристик може свідчити про яскраво виражену індивідуальність та утруднення в дотриманні правил нормативної поведінки, які визначають ті чи інші соціальні ролі. Лише баланс соціальних ролей та індивідуальних характеристик, коли особа має чіткі уявлення про свої соціальні ролі і приймає власні індивідуальні характеристики, може сприяти успішному встановленню та підтриманню партнерських взаємин i, відповідно, асертивної поведінки. Виходячи 3 цих міркувань, визначалися високий, середній та низький рівні рефлексивно-оцінного компонента асертивної поведінки. Високий рівень визначався в разі емоційної врівноваженості, високого рівня рефлексії та балансу соціальних ролей та індивідуальних характеристик, низький - у разі приналежності досліджуваного до емоційно-полярного типу, низького рівня рефлексії та яскраво вираженого дисбалансу зазначених ним соціальних ролей та індивідуальних характеристик. Усі інші співвідношення показників було віднесено до середнього рівня рефлексивно-оцінного компонента.

Високий рівень професійної ідентичності визначався, коли досліджувані позиціонували себе як психолога на перших місцях списку (оскільки вважається, що ті характеристики, які подає людина на початку списку, найбільшою мірою актуалізовані в її свідомості, і є значущими для неї) і позначали всі характеристики, що стосуються професії психолога, знаком «+» [5]. Середній рівень професійної ідентичності було констатовано, коли досліджувані позиціонували себе як психолога посередині списку характеристик, позначаючи при цьому всі характеристики, що мають відношення до професії психолога, знаком «+». Низький рівень професійної ідентичності визначався, коли досліджувані позиціонували себе як психолога на останніх місцях списку або ж взагалі не згадували про себе як майбутнього психолога. Дослідження регулятивного компонента асертивної поведінки здійснювалося за методикою С. Медведєвої «Аналіз і розв'язання професійних ситуа- 
цій» [7], спрямованої на виявлення вмінь майбутніх психологів регулювати свою поведінку в асертивний спосіб при розв'язанні 10 проблемних ситуацій професійної діяльності. Асертивний спосіб регулювання поведінки відповідно до підходу автора визначався за такими показниками: 1) об'єктивний опис ситуації та поведінки в ній; 2) використання конкретних визначень; 3) опис специфічного місця, часу, вчинку, а не припущень про його мотив; 4) відкритий вираз почуттів; 5) активізація емоцій, що ініціюють досягнення мети; 6) спрямованість негативних емоцій на відмову в конкретній ситуації, а не на особистість у цілому. До показників, що свідчили про відсутність асертивного способу регулювання поведінки, віднесено:

1) емоційний опис ситуації без прагнення встановити об'єктивний характер подій; 2) використання абстрактних термінів, висловів на кшталт: «увесь час»; 3) висловлювання припущень про мотиви вчинку; 4) заперечення своїх емоцій і почуттів; 5) неконтрольований вибух емоційних реакцій; 6) використання докорів, погроз тощо. Відповідь за кожну ситуацію, в якій демонструвалося вміння регулювати свою поведінку в асертивний спосіб, оцінювалася в 1 бал; частково асертивний спосіб - 0,5 бала; неасертивний спосіб - 0 балів. Рівні регулятивного компонента асертивної поведінки досліджуваних психологів визначалися за сумарним балом: понад 7 балів - високий; від 3 до 7 - середній, до 3 ба- лів - низький рівень. Узагальнений показник рівня асертивної поведінки визначався 3 таких міркувань: якщо всі компоненти знаходяться на низькому рівні розвитку або один 3 показників - на середньому, то загальний рівень розвитку асертивності трактувався як низький. Якщо всі компоненти високого рівня розвитку або лише один - середнього, то такі результати співвідносились із високим рівнем асертивної поведінки, який визначався вільним володінням і застосуванням асертивного способу регулювання поведінки за високих провідних показниках компонентів асертивної поведінки. Якщо констатовано два компоненти високого рівня розвитку, а два - середнього, то загальний рівень розвитку асертивної поведінки оцінювався як вищий від середнього. Цей рівень характеризується наявністю системи показників асертивної поведінки достатнього рівня і прагненням до асертивного способу регулювання поведінки. Якщо рівень розвитку двох компонентів був низьким, а двох - середнім, то асертивна поведінка визначалася на рівні нижчого від середнього, який відображає наявність недостатньо виражених показників компонентів асертивної поведінки й досить слабкою поінформованістю про показники асертивної поведінки. Усі інші можливі варіанти оцінювалися як середній рівень асертивної поведінки, що визначається наявністю базових основ асертивної поведінки, проте найбільш характерним $є$ нездатність до асертивного способу ре- 
гулювання поведінки. Експериментальна перевірка валідності розробленої нами структури асертивної поведінки та їі емпіричних референтів здійснювалася через співвіднесення отриманих результатів із показниками, що були отримані за шкалою «асертивні дії» методики С. Хобфолла [1;8], яка спрямовувалась на визначення стратегій поведінки у складних ситуаціях. В основу методики С. Хобфолла покладено запропоновану автором багатовісьову модель «поведінки подолання». Така поведінка розглядається ним як стратегії, свого роду тенденції, а не як окремі типи поведінки. Запропонована С. Хобфоллом модель має дві основні вісі: просоціальну - асоціальну, активну - пасивну й одну додаткову: пряму - непряму. Дані вісі являють собою виміри загальних стратегій подолання. У результаті стратегії подолання й моделі поведінки (дії) можна співвіднести їх у такий спосіб: активна - асертивні дії; пасивна - така, що містить обережні дії й уникання; просоціальна - така, що передбачає входження в соціальний контакт і пошук соціальної підтримки; асоціальна - асоціальні й агресивні дії, пряма - імпульсивні дії, непряма - маніпулятивні дії. Досліджуваним пропонувалися твердження щодо поведінки в напружених (стресових) ситуаціях, які необхідно було оцінити в балах залежно від їхньої відповідності власним діям, після чого обраховувалися показники за шкалою «Асертивні дії». В емпіричному дослідженні взяли участь 273 студе- нти-психологи, яких було розподілено на групи за: статтю: 91,6 \% жінок і 8,4 \% чоловіків; віком: до 18 років (34,8\%); 18-21 рік $(24,9$ $\%)$; $21-25$ років (21,6\%); понад 25 років (18,7 \%); курсом навчання: 1 курс $(21,2 \%) ; 2$ курс (21,2 \%); 3 курс (32,7 \%); 4 курс $(24,9$ \%); формою навчання: денна $(61,9 \%)$; заочна Таблиия 1

Розподіл студентів-психологів за рівнями розвитку структурних компонентів асертивної поведінки

\begin{tabular}{|l|c|c|c|}
\hline \multirow{2}{*}{ Компоненти } & \multicolumn{3}{|c|}{$\begin{array}{c}\text { Рівні асертивної } \\
\text { поведінки, } \\
\text { кількість досліджуваних у } \\
\text { \%о }\end{array}$} \\
\cline { 2 - 4 } & $\begin{array}{c}\text { низь- } \\
\text { кий }\end{array}$ & $\begin{array}{c}\text { Серед- } \\
\text { ній }\end{array}$ & $\begin{array}{c}\text { Висо- } \\
\text { кий }\end{array}$ \\
\hline $\begin{array}{l}\text { Ціннісно- } \\
\text { мотиваційний }\end{array}$ & 25,3 & 38,1 & 36,6 \\
\hline Когнітивний & 11,7 & 79,9 & 8,4 \\
\hline $\begin{array}{l}\text { Рефлексивно- } \\
\text { оцінний }\end{array}$ & 17,6 & 60,1 & 22,3 \\
\hline Регулятивний & 18,7 & 66,3 & 15,0 \\
\hline
\end{tabular}

(38,1 \%). Отримані нами результати емпіричного зрізу щодо рівнів сформованості асертивної поведінки за визначеними нами структурними компонентами представлені таблично (табл. 1).

Для ціннісно-мотиваційного компонента асертивної поведінки є високий рівень спря- 
мованості за такими типами: прагматичним (38,1 \%), що орієнтований насамперед на планування професійної діяльності та досягнення успіху в ній; гуманістично-екзистенційним (36,6 \%), за якого цілі, інтереси й потреби інших суб'єктів набувають провідної цінності у поєднанні із прагненням до самоаналізу, самовдосконалення й самореалізації; егоцентричним (25,3\%), за якого цілі, цінності, інтереси, потреби особистості мають переважно егоїстичний характер.

Для когнітивного компонента асертивної поведінки констатовано переважання середнього і низького рівнів сформованості когнітивного компонента асертивної поведінки (79,9 і 11,7 \%) досліджуваних. Встановлено, що у значної частини досліджуваних констатовано середній і низький рівні усвідомлення себе загалом і як майбутнього психолога зокрема (38,8 та 13,2 \% відповідно), при вивченні стану сформованості рефлексивно-оцінного компоненту. Високий рівень емоційної врівноваженості, виваженості у ставленні до інших, здатності розглянути явище з різних сторін встановлено у 11,3 \% досліджуваних; 41,4 $\%$ респондентів характеризуються середнім рівнем емоційної врівноваженості, 47,3 \% низьким.

Виявлено недостатній рівень сформованості рефлексивно-оцінного компонента: високий рівень сформованості виявлено у 22,3 $\%$, середній - у 60,1 \%, низький - у 17,6 \% респондентів. За регулятивним компонентом асертивний спосіб регулювання поведінки властивий 15,0 \% досліджуваним; більшість із них характеризується середнім (66,3%) і низьким $(18,7 \%)$ рівнями регулятивного компоненту. Водночас встановлено, що більшість досліджуваних $(57,5$ \%) перебуває на середньому рівні сформованості асертивної поведінки. Натомість високий рівень спостерігається лише у незначної кількості респондентів (2,6 \%), тоді як низький і нижчий від середнього виявлено у 8,4 \% та у 18,3 \% досліджуваних відповідно.

Висновки. Представлене нами теоретичне обгрунтування структурно-компонентної моделі формування асертивної поведінки та проведене емпіричне обстеження дало можливість зробити висновок про те, що значна кількість майбутніх психологів має недостатній рівень сформованості асертивної поведінки, що й підтверджує актуальність зазначеної нами проблеми та іiі розв'язання на рівні структурних компонентів.

\section{Перспективою подальших досліджень} уважаємо у розробленні соціальнопсихологічного супроводу з урахуванням рівневої диференціації асертивної поведінки у відповідності до розвитку й формування структурних компонентів.

\section{Список використаних джерел:}

1. Бурлачук Л. Ф. Словарь - справочник по психодиагностике / Л. Ф. Бурлачук, С. М. Морозов. - СПб. : Питер, $2002 .-528 \mathrm{c}$.

2. Варфоломеева О. В. Профессиональное становление 
психолога-психотерапевта: [монография] / О. В. Варфоломеева. - К.: ГП «Информационно - аналитическое агентство», 2008. - 428 с.

3. Данилова Т. Н. Опросник диагностики типа направленности личности практического психолога / Т. Н. Данилова // Практична психологія та соціальна робота. - 2004. - № 8. - C. 41- 44.

4. Леонтьев Д. А. Гуманистическая психология как социокультурное явление/ Д.А. Леонтьев // Психология с человеческим лицом: гуманистическая перспектива в постсоветской психологии / [под ред. Д. А. Леонтьева, В. Г. Щур.] - М.: Смысл, 1997. - с. 19-29.

5. Ложкін Г. Особливості становлення ідентичності студентів-спортсменів / Г. Ложкін, В. Воронова, О. Плющ // Науковий вісник Волинського державного університету ім. Лесі Українки. - 1998. - № 3. - С. 146 -150 .

6. Максименко С. Д. Фахівця потрібно моделювати. Наукові основи готовності випускника педвузу до педагогічної діяльності / С. Д. Максименко, О. М. Пелех // Рідна школа. - 1994. -№3-4. - С.68-72.

7. Медведєва C. А. Асертивність майбутніх практичних психологів: досвід вивчення / С. А. Медведєва // Соціальні технологіі: актуальні проблеми теорії та практики: міжвузівський зб. наук. пр. / ред. кол. : В. П. Бех, К. Ю. Богомаз, Л. Ф. Бурлачук та ін. ; гол. ред. О. Л. Скідін. Одеса: Астропринт, 2008. - Вип. 39-40. - С. 234-240.

8. Реан A. А. Психология и психодіагностика личности. Теория, методы исследования, практикум / А. А. Реан. - СПб. : Прайм-ЕВРОЗНАК, 2006. - 255 с.

9. Румянцева Т. В. Психологическое консультирование: діагностика отношений в паре: учебное пособие - СПб.: Речь, 2006. - 176 с.

10. Хохлова Е. В. Конструктивнаяагрессивность в формирование навыков ассертивного поведения студентов вуза: автореф. дисс. ... канд. психол. наук: 19.00.07 «Педагогическая психология» / Хохлова Елена Васильевна; Нижегородский государственный педагогический університет. - Нижний Новгород, 2008. - 26 с.

\section{References (Transliteration):}

1. Burlachuk L. F. Slovar - spravochnik po psihodiagnostike / L. F. Burlachuk, S. M. Morozov. - SPb. : Piter, 2002. $-528 \mathrm{~s}$.

2. Varfolomeeva $O$. V. Professionalnoe stanovlenie psihologa-psihoterapevta: [monografiya] / O. V. Varfolomeeva. - K.: GP «Informatsionno - analiticheskoe agentstvo», 2008. $-428 \mathrm{~s}$.

3. Danilova T. N. Oprosnik diagnostiki tipa napravlennosti lichnosti prakticheskogo psihologa / T. N. Danilova // Praktichna psihologIya ta sotsIalna robota. - 2004. - \# 8. S. $41-44$.

4. Leontev D. A. Gumanisticheskaya psihologiya kak sotsiokulturnoe yavlenie/ D.A. Leontev // Psihologiya s chelovecheskim litsom: gumanisticheskaya perspektiva $\mathrm{v}$ postsovetskoy psihologii / [pod red. D. A. Leonteva, V. G. Schur.] - M.: Smyisl, 1997. - c. 19-29.

5. Lozhkin G. Osoblivosti stanovlennya identichnosti studentIv-sportsmenIv / G. LozhkIn, V. Voronova, O. Plyusch // Naukoviy vIsnik Volinskogo derzhavnogo unIversitetu Im. LesI UkraYinki. - 1998. - \# 3. - S. 146 150.

6. Maksimenko S. D. Fahivtsya potrIbno modelyuvati. NaukovI osnovi gotovnostI vipusknika pedvuzu do pedagogIchnoYi dIyalnostI / S. D. Maksimenko, O. M. Peleh // RIdna shkola. - 1994. \#3-4. - S.68-72.

7. Medvedeva $S$. A. Asertivnist maybutnih praktichnih psihologiv: dosvid vivchennya / S. A. Medvedeva // Sotsialni tehnologii: aktualnI problemi teorIYi ta praktiki: mIzhvuzIvskiy zb. nauk. pr. / red. kol. : V. P. Beh, K. Yu. Bogomaz, L. F. Burlachuk ta In. ; gol. red. O. L. SkIdIn. - Odesa: Astroprint, 2008. - Vip. 39-40. - S. 234-240.

8. Rean A. A. Psihologiya i psihodIagnostika lichnosti. Teoriya, metodyi issledovaniya, praktikum / A. A. Rean. SPb. : Praym-EVROZNAK, 2006. - 255 s.

9. Rumyantseva T. V. Psihologicheskoe konsultirovanie: dIagnostika otnosheniy v pare: uchebnoe posobie - SPb.: Rech, 2006. - $176 \mathrm{~s}$. 
10. Hohlova E.V. Konstruktivnayaagressivnost v formirovanie navyikov assertivnogo povedeniya studentov vuza: avtoref. diss. ... kand. psihol. nauk: 19.00.07 «Pedagogicheskaya psihologiya»/ Hohlova Elena Vasilevna; Nizhegorodskiy gosudarstvennyiy pedagogicheskiy unIversitet. - Nizhniy Novgorod, 2008. - 26 s.

\section{Marchuk Larysa}

Ph.D. in Psychology, Associate Professor of Pedagogy and psychology State higher educational institution «Uzhgorod National University», Uzhgorod (Ukraine)

\section{FORMATION OF ASSERTIVE BEHAVIOR IN STUDENTS PSYCHOLOGISTS: STRUCTURAL AND COMPONENT ANALYSIS}

\section{ABSTRACT}

In the article the views of scientists on the structural component part of assertive behavior are represented; the author's views on the development and formation of university students' assertive behavior are defined and justified. The semantic field of assertive behavior of students in the learning environment is defined. It is determined by the subjectivity of the individual in assertive behavior and expressed in independence, regardless of other circumstances, the ability to defend his/her rights and opinions with esteem and respect for others. Structural components are also defined: value-motivational, reflecting the existence of individual professional manner; cognitive -awareness of content, indexes and factors of assertive behavior, peculiarities of their manifestation in future careers; reflective-evaluative the level of formation of self-esteem, self-worth, self-awareness and self-realization in the educational cooperation; regulatory - the ability to solve problem situations in professional activity in assertive way; control of emotional displays in behavioral situations.

Assertive way of regulating behavior was determined by such indicators as an objective description of the situation and conduct in it; use of specific definitions; description of a specific location, time, action, without speculation about its motives; free expression of feelings; activation of emotions that trigger achieving the goal; directing negative emotions to a refusal in a particular situation, not to a person in general. Indicators of absence of the assertive way of regulating behavior include: description of the situation without emotional desire to establish objective nature of the events; using abstract terms, expressions like "all the time"; statements of assumptions about the motives of the act; denial of own emotions and feelings; uncontrolled explosion of emotional reactions; use of accusations, threats, etc. The indicators and their criteria made it possible to form the levels of assertive behavior in studentspsychologists: high, medium and low.

Insufficient level of formation of assertive behavior in students was stated on the basis of empirical research. It confirmed the relevance of our problems and outlined their decision on the level of structural components.

Keywords: assertiveness, students assertive behavior, structural components, learning environment, social role. 


\section{Марчук Лариса Николаевна}

Кандидат психологических наук, доиент кафедры педагогики и психологии ГВУЗ «Ужсгородский национальный университет»., г. Ужггород (Украина)

\section{ФОРМИРОВАНИЕ АССЕРТИВНОГО ПОВЕДЕНИЯ СТУДЕНТОВ - ПСИХОЛО- ГОВ: СТРУКТУРНО-КОМПОНЕНТНЫЙ АНАЛИЗ ИССЛЕДОВАНИЯ}

Аннотация. В статье раскрыты взгляды ученых на структурно-компонентную составляющую ассертивного поведения; определены и обоснованы собственные соображения по развитию и формированию асертивного поведения студентов в современных вузах. Определено содержание ассертивного поведения студентов в учебной среде, что обусловлено субъектностью личности в самоутвердительном поведении и выражается в самостоятельности, независимости от других обстоятельств, в умении отстаивать свои права и мнение при самоуважении и уважении к другим людям. Структурными компонентами определены: ценностно-мотивационный, когнитивный, рефлексивно-оценочный, регулятивный. На основе эмпирических срезов констатировано недостаточный уровень сформированности ассертивного поведения у студентов, подтверждает актуальность обозначенной нами проблемы и ее решения на уровне структурных компонентов.

Ключевые слова: ассертивность, ассертивное поведение студентов, структурные компоненты, учебная среда, межличностные взаимодействия. 